\title{
THE MEDIATING EFFECT OF INTEREST ON THE RELATIONSHIP BETWEEN DEMORAPHIC ASPECTS AND THE DECISION FOR BEING AND ENTREPRENEUR
}

\author{
Arief Tukiman Hendrawijaya \\ Teacher Training and Education Faculty, University of Jember \\ Jember, East Java, Indonesia
}

\begin{abstract}
The study analyzes the effect of age, education, gender, experience, and the number of family members on the interest to be an entrepreneur and entrepreneurial decision. In addition, the study tests whether the interest to be an entrepreneur mediates the effect of age, education, gender, experience, and family number on the decision to be an entrepreneur. The population of the study are the street vendors in the Jember downtown. The samples consist of 192 respondents. This research uses the path analysis to determine the direct and indirect effects. The results show that age, education, gender, experience, and the number of family member have positive and significant effects on interest and the decision to become an entrepreneur. Interest mediates the effect of age, education, gender, experience, and the number of family member on the decision to become an entrepreneur.
\end{abstract}

Keywords: age, education, socio-economic status, community, family, interest, decision to become an entrepreneur

\section{INTRODUCTION}

The literature suggests that there are many factors associated with the intention to be an entrepreneur. These factors can be classified as internal and external factors. For example, Autio (2005) and Terjesen \& Szerb (2008) showed that the intention to form a business is determined by age. Younger entrepreneurs are more innovative and are more risk-seeking than older ones (Terjesen and Szerb, 2008). Warr (1994) asserts that age is a significant determinant of individual performance.

\footnotetext{
*Corresponding Author.

e-mail: ath.wijaya@gmail.com
} 
Other studies report the positive effect of education level on the ambition to establish a business (Autio, 2005; Terjesen and Szerb, 2008). Nascent entrepreneurs are positively affected by education level (Terjesen and Szerb, 2008). Interestingly, Autio (2005) showed that this effect holds true either for nascent or young business-owners.

Another study shows a negative relationship between time spent with family and the ambition for growth of the entrepreneur (Cliff, 1998). Longer time spent with the family will reduce the hours spent in the company. However, Lau and Busenitz (2001) documented a positive relationship between time commitment and the intention to grow the firm.

Given the empirical findings above, it is interesting to further study the determinants of entrepreneurial interest and the decision to be an entrepreneur. A specific study focusing on the demographic factors (internal factors) is greatly needed. To fill this gap, the current study tries to focus on the street vendors in downtown Jember.

One form of entrepreneurship that is booming lately is the street vendors. Street vendors have become a part of consumer behavior in meeting their needs and wants. Street vendors will not survive if they do not have an interest in entrepreneurship, given the enormous obstacles and challenges. Street vendors have a strong interest in entrepreneurship. If they fail in a particular type of business, they will not give up and just stop, but they will still be self-employed by constantly trying other types of businesses.

The facts show that some street vendors in Jember downtown are those who have been entrepreneurs for more than ten years with the same type of business since the beginning. Some of them are those who have long been entrepreneurs but have experienced changes in the products they sell due to failures with initial products. Some are new traders who tried to reap profits and success with entrepreneurship in the Jember downtown. Others are now no longer operating. One factor that makes the survival of street vendors regarding their businesses in Jember downtown is mostly based on their strong interest in entrepreneurship. The weak interest in entrepreneurship makes the street vendors unable to maintain their business. They do not even want to change to other products. Thus, it becomes important to find out the forming factors of the interest and decision to become entrepreneurs among street vendors and to 
identify the dominant affecting factors. The factors that are expected to affect the interests and decisions to become entrepreneurs among street vendors are age, education, community, and family.

Based on the descriptions above, it is interesting to study and analyze the effect of age, education, socio-economic status, community, and family on the decision to become entrepreneurs, both directly and indirectly by mediated interest.

\section{LITERATURE REVIEW AND HYPOTHESES DEVELOPMENT}

Calá et al. (2015) reviewed the literature on the factors that determine entrepreneurship, both in developing and developed countries. They found that the discriminating factors of entrepreneurship between developing and developed countries include income and financing, public policies and knowledge, macroeconomic stability, industrial structure, and income.

Gartner (1985) showed that individual characteristics are related to the newly created companies' performance, which include the environment characteristics, individual behavior, and the nature or type of business. Bird (1988) showed that entrepreneurial intentionality is determined by both personal characteristics and environmental factors. The personal factors could be related to founding reasons and personality traits. The environmental factors comprise the openness and competitiveness in the domestic market, the policy and programs of the government, cultural and social norms, business and professional infrastructure, access to physical infrastructure, ûnancial support, and education and training.

Empirical evidence shows that entrepreneurial intention is determined by demographic factors. For example, age is positively related to the intention to be an entrepreneur (Davidson, 1991). Interestingly, Miller (1984) found a negative relationship. Nwibo and Okorie (2013) reported that age, education level, gender, marital status, and family size are significantly related to the level of entrepreneurship among Nigerian agribusiness. Gomezelj and Kusce (2013) show that initial personal reasons, the need for independence, and propensity for risk affect business performance. Cuervo (2005) summarizes two types of personal characteristics of entrepreneurship, the psychological and non-psychological 
elements. Entrepreneurship intention is controlled by personal optimism, selfefficacy, and the propensity for risk-taking (Talebi et al., 2014). Giannetti and Simonov (2004) and Martin and Paula (2007) showed that entrepreneurship is determined by socio-economic factors, personality characteristics, and the cultural environment. These factors formed the ingredients for formulating suitable policies to actualize the entrepreneurial development.

Other studies, such as, Scherer et al. (1990), Henley (2005), Bergmann and Sternberg (2007), Leoni and Falk (2008), Mulira et al. (2011), and Garba et al (2013) showed that entrepreneurship is determined by demographic factors. Gender has a positive effect on entrepreneurship. Age and family background are significant determinants of entrepreneurship (Garba et al., 2013). Minniti (2009) reviewed the literatures and found that demographic factors (age, marital status, education level, income and wealth, fear of failure, self-efficacy, work status, opportunity recognition, networks and role models, job satisfaction, social capital, ethnicity and migration status, child-rearing, and quality of life) affect entrepreneurship intention. The decision for entrepreneurship is determined by environmental factors that affect entrepreneurs ( $\mathrm{Fu}, 2016)$.

The aforementioned theoretical explanation and evidence clearly show that there are many factors that determine the intention to be an entrepreneur. They are not only limited to personal traits but also external factors. The current study focuses on the demographic factors. Five demographic factors are examined, namely age, education, gender, experience, and the number of family members on the interest to be an entrepreneur and entrepreneurial decision. The following parts explore the development of hypotheses.

Relationship between Age, Education, Gender, Experience, the Number of Family Members, Interest, and Decision for Entrepreneurship

The general view shows that older people are no more effective than younger people in carrying out certain tasks. This is mainly due to age factors (Gelderblom, 2006). The body of old people is not as strong as that of the younger ones to perform certain tasks with the same efficiency. One important difference between parents and young people in terms of psychological aspects is that old people can perform better than younger ones in doing certain tasks 
because of experience. For example, old people can give better advice than young ones. Robbins and Judge (2013) pointed out that if research separates between professionals and non-professionals, it will be found that performance levels tend to increase in professionals with increasing age, while in nonprofessionals performance decreases with age. The study found that age has a significant, positive effect on interest. Someone is usually more attentive to work and social work during his early adulthood. In this case, the individuals try to prove their socio-economic status (Potter and Perry, 2005).

Age is a determinant of individual performance; that is, individuals' performance will gradually increase or decrease in line with age depending on their work (Warr, 1994). Some important differences between old people and young people is how they deal with psychological aspects, too. On certain tasks, old people can perform better than younger ones because of experience. For example, old people can give better advice than younger people (Gelderblom, 2006). Research by Orser and Foster (1992) found that business owners aged 40 years and over can produce more than those aged less than 40 years old would.

Age is closely related to employees' maturity. Maturity is the level of technical ability in carrying out tasks as well as psychological maturity. The older people grow, the more mature they are. In addition, the psychological aspect will show the maturity of the soul.

Interest can be related to the movement ability that drives us to deal with or face people, things, or any activity that can be an effective experience stimulated by the activity itself. Interest can be the reason why individuals are involved in an activity with a sense of wanting to do, so that there is an encouragement in the individual to do something that is interesting to him and he wants to get involved in the activity. Interest can be defined as an encouragement in individuals based on their likes and interests in things and activities that encourage individuals to behave. Interest is closely related to motivation, motives, and emotional reactions (Crow and Crow, 1992).

Education has a significant positive effect on entrepreneurial interest in Nigeria (Ekpe and Mat, 2012). This is supported by the findings of Ajzen (1991), Carter and Shaw (2006), Gatewood et al. (2004) and Shane (2003), confirming that education is positively related to entrepreneurial interest, while some other studies by Ibru (2009) and Salman (2009) failed to support these findings. The 
higher the educational background, the higher is the interest to run a business (Jorgensen and Margareth, 2010).

Education as an indicator of a person's level of skill or productivity (Benson et al., 2004) and is often used as a prerequisite in making decisions. In a company, employees with higher education contribute only little to the effectiveness of the organization than the educated workers. The higher costs of placing staff with highly educated workers are not possible. Many organizations subsidize employees to obtain a bachelor's or advanced degree (Benson et al., 2004) but do not appropriately assess short-term returns (for example, better performance) or long-term returns (for example, increased work commitments) of the investment.

Gender is a factor that significantly influences a person to start a new business. In this case, men are more encouraged to run a business as a means of obtaining a living to feed the family. Empirical study confirms this prediction (Nwibo and Okorie, 2013). Thus, men have stronger intention to start a business than women.

A person who has failed in starting a business will have a stronger intention to return to work. Failing does not mean stopping to try a new business. A person with longer experience in running businesses is perceived to have stronger motivation to stay in the business rather than the younger and less experienced one. Orser and Foster (1992) found support of this contention.

Social interaction in the family is based on sympathy. An individual first learns to pay attention to the wishes of others, learns to work together, helps to help; in other words, someone first learns to play a role as a social being with certain norms and skills in association with other people. The work of parents who work alone and open their own businesses tends to influence their children to become entrepreneurs. In recent years, many economists have stated that entrepreneurial spirit is closely related to the size of the company itself (Gicheva and Link, 2016).

Family is a collection of two or more people who live together with the rules of a bond, emotion, and each individual in it has respective roles which are part of the family (Friedman, 1998). Family is the smallest unit of society consisting of a husband and a wife and children. Family can affect someone to become an entrepreneur, especially related to the number of family members. 
Parents who work alone or have their own business tend to affect their children to become entrepreneurs (Aldrich and Cliff, 2003).

Based on the descriptions above, the hypotheses are proposed below:

$\mathrm{H}_{1}$ : Age has a positive effect on interest to start a business.

$\mathrm{H}_{2}$ : Education has a positive effect on interest to start a business.

$\mathrm{H}_{3}$ : Gender has a positive effect on interest to start a business.

$\mathrm{H}_{4}$ : Experience has a positive effect on interest to start a business.

$\mathrm{H}_{5}$ : Number of dependent family members has a positive effect on interest to start a business.

$\mathrm{H}_{6}$ : Age has a positive effect on decision for entrepreneurship.

$\mathrm{H}_{7}$ : Education has a positive effect on decision for entrepreneurship.

$\mathrm{H}_{8}$ : Gender has a positive effect on decision for entrepreneurship.

$\mathrm{H}_{9}$ : Experience has a positive effect on decision for entrepreneurship.

$\mathrm{H}_{10}$ : Number of dependent family members has a positive effect on decision for entrepreneurship.

$\mathrm{H}_{11}$ : Interest has a positive effect on decision for entrepreneurship.

$\mathrm{H}_{12}$ : Interest of being an entrepreneur mediates the relationship between age and the decisions of being the entrepreneur.

$\mathrm{H}_{13}$ : Interest of being an entrepreneur mediates the relationship between education and the decisions of being the entrepreneur.

$\mathrm{H}_{14}$ : Interest of being an entrepreneur mediates the relationship between gender and the decisions of being the entrepreneur.

$\mathrm{H}_{15}$ : Interest of being an entrepreneur mediates the relationship between experience and the decisions of being the entrepreneur.

$\mathrm{H}_{16}$ : Interest of being an entrepreneur mediates the relationship between the number of dependent family members and the decisions of being the entrepreneur.

\section{RESEARCH METHODS}

The target population was street vendors in the Jember downtown, totaling at 366 sellers. The samples consisted of 192 street vendors aged above 40 years old. The main data was collected, from March to April 2019, using questionnaires. 
Measurement of age variables used data on respondents' age at the time of the study carried out in unit of year. The measurement of education variables used 5 scales, namely not attending school/not completing elementary school (1), elementary school (2), junior high school (3), high school (4) and college (6). Questions in questionnaires were used as instruments to obtain and validate relevant data in gender, experience, number of dependent family members, interests, and development of decisions for entrepreneurship.

Path analysis is used as a method of data analysis aimed at knowing the direct effect of age, education, socio-economic status, community, and family on decisions for entrepreneurship and the indirect effect of age, education, gender, experience, and number of dependent family members on decisions for entrepreneurship mediated by interest.

\section{RESULTS AND DISCUSSION}

\section{Respondents' Data}

Table 1 Data on Respondents' Characteristics

\begin{tabular}{|l|l|c|c|}
\hline \multirow{2}{*}{ Characteristics } & \multicolumn{1}{|c|}{ Description } & \multicolumn{2}{c|}{ Distribution } \\
\cline { 3 - 4 } & <25 years & Frequency & Percentage (\%) \\
\hline Age & 25-35 years & 146 & 10.9 \\
& $>$ 35 years & 25 & 76.0 \\
& Junior High School & 88 & 13.0 \\
\hline Education & Senior High School & 100 & 45.8 \\
& College & 4 & 52.1 \\
& Male & 76 & 2.1 \\
\hline Sex (gender) & Female & 116 & 39.6 \\
& $<1$ year & 49 & 60.4 \\
\hline Experience & 1-5 years & 87 & 25.5 \\
& $>5$ years & 56 & 45.3 \\
& <2 & 60 & 29.2 \\
\hline Number of & 2-3 & 53 & 31.3 \\
dependent & 4-5 & 41 & 27.6 \\
family & $>5$ & 71 & 21.4 \\
members & < IDR 1,500,000 & 19.8 \\
\hline Income & IDR 1,500,001 - 3,000,000 & 66 & 37.0 \\
& IDR 3,000,001 - 4,500,000 & 37 & 34.4 \\
& $>$ IDR 4,500,000 & 18 & 19.3 \\
& Total & 192 & 9.4 \\
\hline
\end{tabular}


This research took a sample of 192 respondents consisting of street vendors in Jember downtown. Data on respondents' characteristics include age, gender, education, length of trading experience, and total income. The descriptions for each of these characteristics are presented in Table 1.

The general description of respondents shows that most of the research respondents are aged 25-35 (76.0\%), high school-educated (52.1\%), and femalegendered (60.4\%). Most of the research respondents have been street vendors for 1-5 years (45.3) and have an income of less than IDR 1,500,000 (37.0\%). In addition, most of the respondents are having one dependent family member (31.3\%).

All the data in Table 1 are converted into ordered categories except for the sex category. For example, age below 25 is scored 1, age between 25 and 35 is scored 2, and age above 35 is scored 3. The same treatment is applied to education, length of service (experience), and number of dependent family members.

\section{Data Quality Test}

The results of the data validity test on variables of socio-economic status, community, family, interests, and decision on entrepreneurship show a correlation coefficient between 0.150 to 0.858 with a significance value between 0.000 and 0.038 , indicating a significance value that is less than a $(0.05)$. This means that all items on the variables of socio-economic status, community, family, interests and decision for entrepreneurship are valid. Instrument reliability testing obtained Cronbach's Alpha coefficient values of 0.816 (gender), 0.605 (experience), 0.712 (number of dependent family members), 0.602 (interest), and 0.833 (decision for entrepreneurship). The Cronbach's Alpha coefficient values are greater than 0.60 , so the variable instruments of gender, experience, and interests are declared reliable (Hair et al., 2010).

\section{Path Analysis}

The results of testing the direct effect of the variables of age, education, socio-economic status, community, and family on the interests and variables of 
age, education, socio-economic status, community, family, and interest on decision for entrepreneurship are presented in Table 2.

Table 2 Hypothesis Testing on Direct Effect

\begin{tabular}{|c|l|c|c|c|}
\hline Hypothesis & \multicolumn{1}{|c|}{ Regression Model } & Direct Effect & t-count & Sig. \\
\hline $\mathrm{H}_{1}$ & Age $\left(\mathrm{X}_{1}\right) \rightarrow$ Interest $(\mathrm{Z})$ & 0.165 & 3.241 & $0.001 * *$ \\
\hline $\mathrm{H}_{2}$ & Education $\left(\mathrm{X}_{2}\right) \rightarrow$ Interest $(\mathrm{Z})$ & 0.168 & 3.588 & $0.000 * *$ \\
\hline $\mathrm{H}_{3}$ & Gender $\left(\mathrm{X}_{3}\right) \rightarrow$ Interest $(\mathrm{Z})$ & 0.210 & 3.785 & $0.000 * *$ \\
\hline $\mathrm{H}_{4}$ & Experience $\left(\mathrm{X}_{4}\right) \rightarrow$ Interest $(\mathrm{Z})$ & 0.273 & 4.470 & $0.000 * *$ \\
\hline $\mathrm{H}_{5}$ & $\begin{array}{l}\text { Dependent family members }\left(\mathrm{X}_{5}\right) \rightarrow \\
\text { Interest }(\mathrm{Z})\end{array}$ & 0.251 & 3.319 & $0.001 * *$ \\
\hline $\mathrm{H}_{6}$ & $\begin{array}{l}\text { Age }\left(\mathrm{X}_{1}\right) \rightarrow \text { Decision for } \\
\text { Entrepreneurship (Y) }\end{array}$ & 0.065 & 2.227 & $0.027 *$ \\
\hline $\mathrm{H}_{7}$ & $\begin{array}{l}\text { Education }\left(\mathrm{X}_{2}\right) \rightarrow \text { Decision for } \\
\text { Entrepreneurship (Y) }\end{array}$ & 0.079 & 2.908 & $0.004 * *$ \\
\hline $\mathrm{H}_{8}$ & $\begin{array}{l}\text { Gender }\left(\mathrm{X}_{3}\right) \rightarrow \text { Decision for } \\
\text { Entrepreneurship (Y) }\end{array}$ & 0.065 & 2.029 & $0.044 *$ \\
\hline $\mathrm{H}_{9}$ & $\begin{array}{l}\text { Experience }\left(\mathrm{X}_{4}\right) \rightarrow \text { Decision for } \\
\text { Entrepreneurship (Y) }\end{array}$ & 0.075 & 2.086 & $0.038 *$ \\
\hline $\mathrm{H}_{10}$ & $\begin{array}{l}\text { Dependent family members }\left(\mathrm{X}_{5}\right) \rightarrow \\
\text { Decision for Entrepreneurship }(\mathrm{Y})\end{array}$ & 0.089 & 2.029 & $0.044 *$ \\
\hline $\mathrm{H}_{11}$ & $\begin{array}{l}\text { Interest }(\mathrm{Z}) \rightarrow \text { Decision for } \\
\text { Entrepreneurship (Y) }\end{array}$ & 0.697 & 16.937 & $0.000 * *$ \\
\hline
\end{tabular}

Table 2 shows that the results of testing the direct effect on all variables have a coefficient marked positive which means that each increase in exogenous

Table 3 Hypothesis Testing of Indirect Effect

\begin{tabular}{|c|l|c|c|c|}
\hline Hypothesis & \multicolumn{1}{|c|}{ Regression Model } & $\begin{array}{c}\text { Indirect } \\
\text { Effect }\end{array}$ & t-count & Sig. \\
\hline $\mathrm{H}_{12}$ & $\begin{array}{l}\text { Age }\left(\mathrm{X}_{1}\right) \rightarrow \text { Interest }(\mathrm{Z}) \rightarrow \text { Decision } \\
\text { for Entrepreneurship (Y) }\end{array}$ & 0.148 & 3.178 & $0.002 * *$ \\
\hline $\mathrm{H}_{13}$ & $\begin{array}{l}\text { Education }\left(\mathrm{X}_{2}\right) \rightarrow \text { Interest }(\mathrm{Z}) \rightarrow \\
\text { Decision for Entrepreneurship }\end{array}$ & 0.832 & 3.504 & $0.001 * *$ \\
\hline $\mathrm{H}_{14}$ & $\begin{array}{l}\text { Gender }\left(\mathrm{X}_{3}\right) \rightarrow \text { Interest }(\mathrm{Z}) \rightarrow \\
\text { Decision for Entrepreneurship }\end{array}$ & 0.181 & 3.688 & $0.000 * *$ \\
\hline $\mathrm{H}_{15}$ & $\begin{array}{l}\text { Experience }\left(\mathrm{X}_{4}\right) \rightarrow \text { Interest }(\mathrm{Z}) \rightarrow \\
\text { Decision for Entrepreneurship }\end{array}$ & 0.303 & 4.315 & $0.000 * *$ \\
\hline $\mathrm{H}_{16}$ & $\begin{array}{l}\text { Dependent family members }\left(\mathrm{X}_{5}\right) \rightarrow \\
\text { Interest }(\mathrm{Z}) \rightarrow \text { Decision for } \\
\text { Entrepreneurship }\end{array}$ & 0.232 & 3.251 & $0.002 * *$ \\
\hline
\end{tabular}


variables (age, education, gender, experience, and dependent family members) will be followed by an increase in endogenous variables (interest and decision for entrepreneurship). The results of testing the effect of (indirect) mediation of interest on age, education, gender, experience, and dependent family members on decision for entrepreneurship are presented in Table 3.

The results of hypothesis testing on the path of indirect effect show that all indirect pathways have a very significant effect, which means that interest is able to mediate the effect of age, education, gender, experience, and dependent family members regarding decision for entrepreneurship. The recapitulation of the results of the testing of direct effect, indirect effect, and total effect between exogenous variables (age, education, gender, experience, and dependent family members) on endogenous variables (interest and decision for entrepreneurship) are presented in Table 4.

Table 4 Direct, Indirect and Total Effects

\begin{tabular}{|l|c|c|c|}
\hline \multicolumn{1}{|c|}{ Regression Model } & $\begin{array}{c}\text { Indirect } \\
\text { Effect }\end{array}$ & $\begin{array}{c}\text { Direct } \\
\text { Effect }\end{array}$ & $\begin{array}{c}\text { Total } \\
\text { Effect }\end{array}$ \\
\hline Age $\left(\mathrm{X}_{1}\right) \rightarrow$ Decision for Entrepreneurship $(\mathrm{Y})$ & 0.065 & 0.148 & 0.213 \\
\hline Education $\left(\mathrm{X}_{2}\right) \rightarrow$ Decision for Entrepreneurship $(\mathrm{Y})$ & 0.079 & 0.832 & 0.911 \\
\hline Gender $\left(\mathrm{X}_{3}\right) \rightarrow$ Decision for Entrepreneurship $(\mathrm{Y})$ & 0.065 & 0.181 & 0.246 \\
\hline Experience $\left(\mathrm{X}_{4}\right) \rightarrow$ Decision for Entrepreneurship $(\mathrm{Y})$ & 0.075 & 0.303 & 0.378 \\
\hline $\begin{array}{l}\text { Dependent family members }\left(\mathrm{X}_{5}\right) \rightarrow \text { Decision for } \\
\text { Entrepreneurship }(\mathrm{Y})\end{array}$ & 0.089 & 0.232 & 0.320 \\
\hline
\end{tabular}

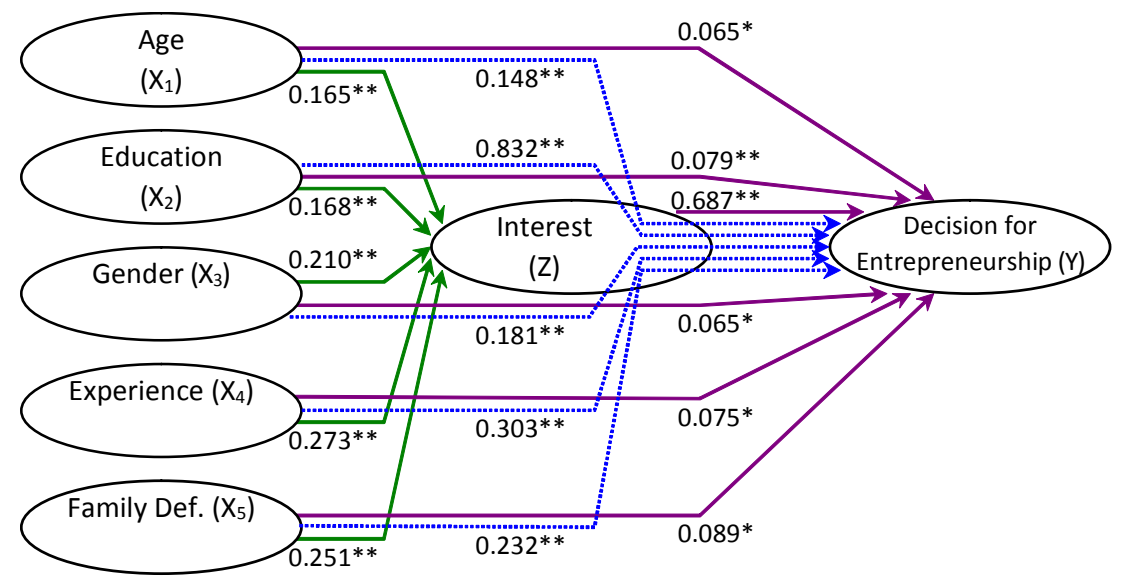

Figure 1 Path Coefficient of Direct and Indirect Effects 
Based on Table 4, it is known that each of the total effect of the independent variables is age by $21.3 \%$, education by $91.1 \%$, gender by $24.6 \%$, community by $37.8 \%$, and family by $32.0 \%$. The results of the path analysis test are presented in Figure 1.

\section{Discussion}

Age has a positive and significant effect on interest. This means that the higher the age, the higher the interest in entrepreneurship will be. Some important differences between old people and young people are related to psychological aspects. On certain tasks, old people can perform better than younger ones because of experience. For example, old people can give better advice than younger people (Gelderblom, 2006).

Education has a positive and significant effect on interest. This can be interpreted that higher education will be able to increase interest in entrepreneurship. One effort to increase the number of entrepreneurs is through education. Education has a very strategic role in improving the quality of human resources, overcoming the unemployment rate and fostering interest or intention, entrepreneurial talent, as well as efforts to actualize the future of the Indonesian nation in actualizing public welfare and educating the people of the nation.

The test results show that gender has a positive and significant effect on interest which means that indicators in gender can increase respondents' interest in entrepreneurship. Experience has a positive and significant effect on interest, which means that indicators in community can increase interest in entrepreneurship. Dependent family members have a positive and significant effect on interest, meaning that indicators in family can increase interest in entrepreneurship.

One aspect of the interest in entrepreneurship is the sociological role, which is related to relationships with family and other social relations. Family relationship can be seen from parents, work, and social status. Social factors that affect the interest in entrepreneurship are of family responsibility. In addition to the work of parents, it is often seen that parents who work alone and have their own business tend to affect their children to be entrepreneurs. This situation often inspires someone to become an entrepreneur. A person will become a 
successful entrepreneur if he thinks of something new or uses something old in a new way (Zimmemer and Scarborough, 2002).

This study found that age has a positive and significant effect on decisions for entrepreneurship. This means that the higher the age, the more courageous people are in making decisions in entrepreneurship. Orser and Foster (1992) suggested that business owners aged 40 years and over have the opportunity to produce more than those aged less than 40 years, especially in terms of decision making.

Education has a positive and significant effect on decision for entrepreneurship. This means that high education will ripen them in making decisions for entrepreneurship. Education is very important for every human being because without education, people cannot get or have knowledge. The most important education starts in the family, which is the first place to provide education for children. From a family, children receive guidance on personality or behavior carried out by children to academic matters. Education plays a role as an indicator of a person's level of skill or productivity (Benson et al., 2004) and is often used as a prerequisite in making decisions.

Decision for entrepreneurship is also influenced by gender. Experience has a positive and significant effect on decisions for entrepreneurship which means that indicators in the community can improve decisions for entrepreneurship. The driving factor for entrepreneurship found that experience affect a person to become an entrepreneur because it is mostly driven by brothers/sisters and neighbors who are entrepreneurs and also the surrounding communities where self-employed people exist and live in an entrepreneurial community.

The number of dependent family members has a positive and significant effect on decision for entrepreneurship, which means that indicators in the family environment can improve decision for entrepreneurship. A person's decision to become an entrepreneur is supported by factors from the family. Someone who is raised by parents who are self-employed, tends to follow parents' footsteps because he has gained experience from the parents. This shows an entrepreneurial culture formed in the family. The family can affect someone to become an entrepreneur, especially related to the parents' work. The work of parents who have their own business tends to affect children to become entrepreneurs (Aldrich and Cliff, 2003). 
Interest has a significant positive effect on decisions for entrepreneurship. This can be interpreted as how indicators in interest can improve decisions for entrepreneurship. An entrepreneur can respond to a business opportunity both positively and negatively, be innovative in finding new ideas or ways, take risks by calculating the possibility of success and failure, favor hard work to always be involved in work situations, and to not give up easily. Besides, a female entrepreneur who has an entrepreneurial attitude will be able to respond to a business opportunity and will have an innovative turnaround to develop new ideas, will be more willing to take risks, and will always work hard, and will not easily give up in running a business.

Age affects decisions for entrepreneurship mediated by interest. This means that interest variables can mediate the effect of age on decisions for entrepreneurship. The direct effect of age on decisions for entrepreneurship is $6.5 \%$, while the indirect effect of age on decisions for entrepreneurship is mediated by interest by $14.8 \%$. This shows that indirect effects outweigh the direct effect of age decisions for entrepreneurship without going through interests. This means that interest can mediate the effect of age on decisions for entrepreneurship. This result is seen from the significance value of 0.002 , which is smaller than á (0.05).

Education affects decisions for entrepreneurship mediated by interest. This means that interest variables can mediate the effect of education on decisions for entrepreneurship. The direct effect of education on decisions for entrepreneurship is $7.9 \%$, while the indirect effect of education on decisions for entrepreneurship is mediated by interest of $83.2 \%$. This shows that indirect effect (with mediated interest) is greater than the direct effect of education on decisions for entrepreneurship. This means that interest can mediate the effect of education on decisions for entrepreneurship. This result is seen from the significance value of 0.001 , which is smaller than á (0.05).

The direct effect of gender on decisions for entrepreneurship is 6.5\%, while the indirect gender effect on decisions for entrepreneurship is mediated by interest of $18.1 \%$. This shows that indirect effects outweigh the direct gender effects of decisions for entrepreneurship. This means that interest can mediate gender effect on decisions for entrepreneurship. This result is seen from the significance value of 0.000 , which is smaller than á (0.05). 
Experience affects decisions for entrepreneurship mediated by interest. This means that interest variables can mediate the effect of experience on decisions for entrepreneurship or that indicators in the community can improve decisions for entrepreneurship supported by interest. The direct effect of experience on decisions for entrepreneurship is $7.5 \%$, while the indirect effect of experience on decisions for entrepreneurship is mediated by interest of $30.3 \%$. This shows that indirect effects outweigh the direct effect of the experience on decisions for entrepreneurship. It means that interest can mediate the effect of the community on decisions for entrepreneurship. This result is seen from the significance value of 0.000 , which is smaller than á (0.05).

Dependent family members affect decisions for entrepreneurship mediated by interest. This means that interest variables can mediate the effect of dependent family members on decisions for entrepreneurship or indicators in family can increase decisions for entrepreneurship supported by interest. The direct effect of dependent family members on entrepreneurial decisions is $8.9 \%$, while the indirect effect of family on decisions for entrepreneurship is mediated by interest of $23.2 \%$. This shows that indirect effect outweighs the direct effect of family on decisions for entrepreneurship. This means that interest can mediate the effect of dependent family members on decisions for entrepreneurship. This result is seen from the significance value of 0.002 , which is smaller than a $(0.05)$.

\section{CONCLUSION}

This study was conducted on 192 street vendors in Jember to study and analyze the factors that affect decisions for entrepreneurship, both directly and indirectly. The results of the study show that the variables of age, education, gender, experience, and dependent family members directly have a positive and significant effect on interests in and decisions for entrepreneurship. The indirect interest is able to mediate the effect of variables of age, education, gender, experience, and dependent family members on decisions for entrepreneurship in Jember downtown.

The limitation in this study is that this research was carried out on street vendors with various commodities, so that they have not been specified in one commodity. Future research can be carried out by exploring broader research 
variables such as experience in trading, capital or expertise possessed. In addition, research can also be carried out on sellers who sell only one commodity.

\section{REFERENCES}

Ajzen, I. 1991. The Theory of Planned Behavior. Organizational Behavior and Human Decision Processes, 50(2): 179-211.

Aldrich, H.E. and J.E. Cliff. 2003. The Pervasive Effects of Family on Entrepreneurship: Toward a Family Embeddedness Perspective. Journal of Business Venturing. 18 (2003): 573-596.

Autio, E. 2005. Global Entrepreneurship Monitor: 2005 Report on High-Expectation Entrepreneurship. London: GEM.

Benson, G.S., D. Finegold, dan S.A. Mohrman. 2004. You Paid for the Skills, Now Keep Them: Tuition Reimbursement and Voluntary Turnover. Academy of Management Journal. 47(1): 315-331.

Bergmann, H. and R. Sternberg. 2007. The Changing Face of Entrepreneurship in Germany. Small Business Economics, 28(2-3): 205-221.

Bird, B. 1988. Implementing Entrepreneurial Ideas: The Case for Intention. Academy of Management Review, 13(3): 442-453.

Calá, C.D., J.M. Arauzo-Carod., and M. Manjón-Antolín. 2015. The Determinants of Entrepreneurship in Developing Countries. Working Paper, Facultad de Ciencias Económicas y Sociales, Universidad Nacional de Mar del Plata, Argentina.

Carter, S. and E. Shaw. 2006. Women's Business Ownership: Recent Research and Policy Developments. UK: Small Business Service.

Cliff, J.E. 1998. Does One Size Fit All? Exploring the Relationship between Attitudes towards Growth, Gender, and Business Size. Journal of Business Venturing 13(6): 523-542.

Crow, A. and L.D. Crow. 1992. Educational Psychology. New Jersey: Littlefield Adams and Co.

Cuervo, A. Individual and Environmental Determinants of Entrepreneurship. International Entrepreneurship and Management Journal, 1, 293-311. 
Davidson, P. 1991. Continued Entrepreneurship: Ability, Need, and Opportunity as Determinants of Small Firm Growth. Journal of Business Venturing, 6(6): 405-429.

Friedman, M.M. 1998. Family Nursing: Theory and Practice. Original English Language Edition Published. Morwalk CT: Apple Ton \& Lange.

Fu, W. 2016. Industrial Clusters as Hothouses for Nascent Entrepreneurs? The Case of Tianhe Software Park in Guangzhou, China. The Annals of Regional Science, 57(1), 253-270.

Garba, A.S., S.A. Mansor, and F. Djafar. 2013. Entrepreneurship and Its Determinants in Nigeria: Empirical Evidence from Micro and Small Enterprises in Kano State. Journal of Entrepreneurship and Management. 2(2): $1-12$.

Gartner, W.B. 2001. Is There an Elephant in Entrepreneurship? Blind Assumptions in Theory Development. Entrepreneurship Theory and Practice, 25(4): 27-39.

Gatewood, E.J., C.G. Brush, N.M. Carter, P.G. Greene, and M.M. Hart. 2004. Women Entrepreneurs, Growth and Implications for the Classroom. USA: Coleman Foundation Whitepaper Series for the USA Association for Small Business and Entrepreneurship.

Gelderblom, A. 2006. In Ageing and Employment: Identification of Good Practice to Increase Job Opportunities and Maintain Older Workers in Employment. The Relationship of Age with Productivity and Wages, European Commission. 67-84.

Gicheva, D. \& Link, A.N. 2016. On the Economic Performance of Nascent Entrepreneurs. European Economic Review, 86(C): 109-117.

Gianneti, M. and Simonov, A. 2004. On the Determinants of Entrepreneurial Activity: Social Norms, Economic Environment and Individual Characteristics. Swedish Economic Policy Review, 11(2): 269-313.

Gomezelj, D.O. and Kusce, I. The Inûuence of Personal and Environmental Factors on Entrepreneurs' Performance. Kybernetes, 42(6): 906-927.

Hair, J.F., William, C.B., Barry, J.B., \& Rolph, E.A. 2010. Multivariate Data Analysis. $7^{\text {th }}$ edition. New Jersey: Pearson Education Inc. 
Henley, A. 2005. Job Creation by the Self-Employment: The Roles of Entrepreneurial and Financial Capital. Small Business Economics, 25(2): 175-196.

Ibru, C. 2009. Growing Microfinance through New Technologies. Akure, Nigeria: Federal University of Technology.

Jorgensen, E. and S.S. Margaret. 2010. From Financial to Financial Capability among the Young. Journal of Sociology and Social Welfare. 34(3): 119-145.

Lau, C. and L.W. Busenitz. 2001. Growth Intentions of Entrepreneurs in a Transitional Economy. The People's Republic of China. Entrepreneurship Theory and Practice, 26(1): 5-20.

Leoni, T. and M. Falk. 2010. Gender and Field of Study as Determinants of SelfEmployment. Small Business Economics, 34(2): 167-185

Martin, S.L. and Paula. S. 2007. Indicators for Measuring Entrepreneurship. A Proposal for a Scoreboard. Industry and Higher Education Journal, 21(1): 85-97.

Miller, R. 1984. Job Matching and Occupational Choice. Journal of Political Economy, 92(6): 1086-1120.

Minniti, M. 2009. Gender Issues in Entrepreneurship. Foundations and Trends in Entrepreneurship, 5(7-8): 497-621

Mulira, F., Namatovu, R. \& Dawa, S. 2011. Panacea or Precipitate: The Entrepreneurship and Poverty Paradox. Retrieved from www.aibuma.org/ proceedings

Nwibo, A.U., and Okorie, A. 2013. Determinants of Entrepreneurship among Agribusiness Investors in South-East, Nigeria. European Journal of Business and Management, 5(10): 115-123.

Orser, B. dan M. Foster. 1992. Home Enterprise: Canadians and Home Based Work. Canada: The Home Based Business Project Committee.

Peter, J.P. and J.C. Olson. 2010. Consumer Behavior and Marketing Strategy. Boston: McGraw Hill.

Potter, A.P. dan G.A. Perry. 2005. Buku Ajar Fundamental Keperawatan: Konsep, Proses, dan Praktik, edisi 4. Jakarta: EGC.

Robbins, S.P. dan T.A. Judge. 2013. Organization Behavior. Boston: Pearson.

Salman, A. 2009. How to Start a Business: A Guide for Women. Pakistan: Center for International Private Enterprise, Institute of National Endowment for Democracy, Affiliate of the USA Chamber of Commerce. 
Scherer, R.F., J.S. Brodzinski, and F.A. Wiebe. 1990. Entrepreneur Career Selection and Gender: A Socialization Approach. Journal of Small Business Management, 28(2): 37-71.

Shane, S. 2003. A General Theory of Entrepreneurship: The Individual-Opportunity Nexus. UK: Edward Elgar.

Talebi, K., P. Nouri., and A.A. Kafeshani. 2014. Identifying the Main Individual Factors Influencing Entrepreneurial Decision Making Biases: A Qualitative Content Analysis Approach. International Journal of Academic Research in Business and Social Sciences, 4(8): 1-11.

Terjesen, S. and L. Szerb. 2008. Dice Thrown from the Beginning? An Empirical Investigation of Firm Level Growth Expectations. Estudios de Economía 35(2): 157-178.

Warr, P. 1994. Age and Job Performance. In J. Snel \& R.R. Cremer (eds.), Work and Aging: A European Perspective. London: Taylor \& Francis. pp. 309322.

Zimmemer, T.W. and N.M. Scarborough. 2002. Essentials of Entrepreneurship and Small Business Management. New Jersey: Pearson Education, Inc. 
Review of Management and Entrepreneurship

Volume 02, Number 02, October 2018 